Analytica Chimica Acta, 99 (1978) 193-i95

๑Elsevier Scientific Publishing Company, Amsterdam - Printed in The Netherlands

Short Communication

\title{
THE DETERMINATION OF SMALL AMOUNTS OF ALUMINIUM AND SILICON IN STABILIZED ZIRCONLA CERAMICS
}

\section{H. KRUIDHOF}

Twente University of Technology, Department of Chemical Engineering, Laboratory of Inorganic Chemistry and Materials Science, Enschede (The Netherlands)

(Received 31st January 1978)

Zirconias, stabilized by the oxides of rare earths, calcium, and yttrium, are applied as solid electrolytes in high-temperature fuel cells, devices for hydrogen production from steam, exhaust control systems and electrode materials. The assay of aluminium and silicon is important because of their influence on the electrical conductivity, but their determination in stabilized zirconias has not been described in the literature; the present communication reports colorimetric methods for their determination in small amounts.

Solutions of samples can be obtained by fusion with a mixture of borax, boric acid, and lithium hydroxide, followed by dissolution in dilute acid. Zirconium and rare earth ions interfere with the determination of aluminium; these constituents are removed by cation exchange and aluminium is determined with chromazurol S. Silicon is measured as molybdenum blue, after the reduction of molybdosilicate.

\section{Experimental}

Reagents and standard solutions. Redistilled water was used for reagent preparation. All chemicals were of analytical grade. The flux was prepared by mixing 45 parts of borax, 16 parts of boric acid, and 7 parts of lithium hydroxide. The buffer solution was prepared by dissolving $27.5 \mathrm{~g}$ of ammonium acetate and $0.5 \mathrm{mi}$ of glacial acetic acid in $50 \mathrm{ml}$ of water, with dilution to $100 \mathrm{ml}$.

The standard silicon solution was obtained by fusing pure silicon dioxide with anhydrous sodium carbonate. The melt was dissolved in water; after suitable dilution, a solution containing $I \mu \mathrm{g} \mathrm{Si} \mathrm{ml}^{-1}$ was prepared. The standard aluminium solution was prepared by dissolving pure aluminium in $6 \mathrm{M}$ hydrochloric acid; this solution was diluted to give $1 \mu \mathrm{g} \mathrm{Al} \mathrm{ml}^{-1}$. The standard solutions can be stored for several weeks in piastic containers.

Preparation of the cation-exchange column. A strong acid cation exchanger (Dowex 50W-X8, 100-200 mesh) was used. The resin was slurried with a few $\mathrm{ml}$ of $6 \mathrm{M}$ hydrochloric acid and, after $10 \mathrm{~min}$, was poured into an ion exchange column (height, ca. $15 \mathrm{~cm}$; diameter, $1 \mathrm{~cm}$ ) filled with the same acid. The resin was pretreated as described below. 
Dissolution of samples. Accurateiy weigh ca. $50 \mathrm{mg}$ of powdered sample into a Pt $-5 \%$ Au crucible and add $500 \mathrm{mg}$ of flux. Mix carefully with a spatula and fuse at $900^{\circ} \mathrm{C}$ for about $10 \mathrm{~min}$.

Procedure for aluminium. Add $5 \mathrm{ml}$ of $6.5 \mathrm{M}$ hydrochloric acid to the melt described above. Heat to ca. $60^{\circ} \mathrm{C}$ until the melt is released from the crucible. Transfer melt and liquid to a graduated beaker, and reheat to $60^{\circ} \mathrm{C}$ until the melt has completely dissolved. Cool and dilute to $20 \mathrm{ml}$ with $6.5 \mathrm{M}$ hydrochloric acid. Add $20 \mathrm{ml}$ of ethanol and mix. Pass the mixture through the ion-exchange column (pretreated witin $60 \mathrm{ml}$ of $6 \mathrm{M}$ hydrochloric acid, $40 \mathrm{ml}$ of water and $50 \mathrm{ml}$ of $3 \mathrm{M}$ hydrochloric acid in $50 \%$ ethanol) at a flow-rate of ca. $0.5 \mathrm{ml} \mathrm{min}^{-1}$. Subsequently wash the resin bed with $150 \mathrm{ml}$ of $3 \mathrm{M}$ hydrochloric acid in $50 \%$ ethanol and combine this effluent in a $250-\mathrm{ml}$ volumetric flask with the effluent obtained from the sample solution. Dilute the solution to the mark. Transfer a 25-ml aliquot to a 50-ml beaker, add three drops of concentrated sulphuric acid and evaporate to dryness on a steam-bath. Add $5 \mathrm{ml}$ of water and neutralize the solution. Transfer the solution to a 50 -mil volumetric flask and add $2 \mathrm{ml}$ of ascorbic acid solution $\left(50 \mathrm{mg} \mathrm{ml}^{-1}\right)$ and $10 \mathrm{ml}$ of buffer solution, followed by $2 \mathrm{ml}$ of chromazurol $\mathrm{S}$ reagent $(0.2 \%$ solution in $25 \%$ ethanol) [1]. Dilute the solution to the mark, shake well, and wait for $15 \mathrm{~min}$. Measure the absorbance in $4 \mathrm{~cm}$ cells at $540 \mathrm{~nm}$ against a blank containing all reagents used. To calibrate the method, transfer aliquots up to $10 \mathrm{ml}$ of standard aluminium solution to $50 \mathrm{-ml}$ volumetric rlasks and treat in the way described above.

Procedure for silicon. Add $8 \mathrm{ml}$ of $3 \mathrm{M}$ hydrochloric acid to the melt obtained after fusion. Heat to ca. $60^{\circ} \mathrm{C}$ until the melt is released from the crucible. Transfer melt and liquid to a plastic beaker and reheat until the melt has dissolved completely. Cool, and transfer the solution to a $50-\mathrm{ml}$ volumetric flask; dilute to the mark. Transfer a $25-\mathrm{ml}$ aliquot to a dry beaker, add $10.0 \mathrm{ml}$ of ammonium molybdate reagent $\left(50 \mathrm{mg} \mathrm{m}^{-1}\right.$ in water), and mix. Wait for $20 \mathrm{~min}$ and add $10.0 \mathrm{ml}$ of oxalic acid solution (40 $\mathrm{mg} \mathrm{ml}^{-1}$ in water). Mix until the sediment has disappeared and immediately add $5.0 \mathrm{ml}$ of ammonium iron(II) sulphate solution $\left(60 \mathrm{mg} \mathrm{ml}^{-1}\right.$ in $0.02 \mathrm{M}$ sulphuric acid). Wait for at least $25 \mathrm{~min}$ and measure the absorbance in $4-\mathrm{cm}$ cells, at $815 \mathrm{~nm}$, against a blank containing all the reagents used. For calibrating the method, transfer aliquots up to $25 \mathrm{ml}$ of standard silicon solution to $50 \mathrm{ml}$ volumetric flasks; add $6.5 \mathrm{ml}$ of $3 \mathrm{M}$ hydrochloric acid, and dilute the solutions to the mark. Transfer 25-ml ciquiots to dry beakers and treat in the way described above.

\section{Results and discussion}

To test the removal of the interfering constituents by cation exchange [2], various zirconias were dissolved, aluminium was added, and the solutions were passed through the column. The aluminium was always present in the first $180 \mathrm{ml}$ of effluent, in which none of the other constituents was present. 
TABLE 1

Recovery of aluminium added to hydrochloric acid solutions containing flux

\begin{tabular}{lllrrrr}
\hline Flux present $(\mu \mathrm{g})$ & - & - & 100 & 100 & 250 & 250 \\
$\mathrm{Al}^{3+}$ added $(\mu \mathrm{g})$ & 5 & 10 & 5 & 10 & 2 & 5 \\
$\mathrm{Al}^{3+}$ found $(\mu \mathrm{g})$ & 4.95 & 10.05 & 5.15 & 9.7 & 1.95 & 5.2 \\
\hline
\end{tabular}

TABLE 2

Recovery of aluminium and silicon added to a sample of stabilized zirconia

\begin{tabular}{llllllll}
\hline $\mathrm{Si}$ & added, \% & 0.008 & 0.016 & 0.020 & 0.024 & 0.030 & 0.036 \\
$\mathrm{Si}$ & found, \% & 0.0081 & 0.0157 & 0.0205 & 0.023 & 0.027 & 0.037 \\
$\mathrm{Al}$ & added, \% & 0.20 & 0.40 & 0.10 & 0.05 & 0.02 & - \\
$\mathrm{Al}$ & found, \% & 0.22 & 0.38 & 0.09 & 0.05 & 0.02 & 0.001 \\
\hline
\end{tabular}

The cation exchanger can be regenerated with $6 \mathrm{M}$ hydrochloric acid. The flux does not interfere with the method, but hydrochloric acid must be removed. Sulphuric acid prevents the loss of aliminium chloride. To test the colorimetric procedure, hydrochloric acid and differen ${ }^{\frac{1}{t}}$ amounts of flux were added to various solutions of aluminium. These solutions, analysed as described under the procedure for aluminium, gave the results in Table 1. This determination is adapted from a method used for silicon in steel [3]. All glassware must be cleaned with $6 \mathrm{M}$ hydrochloric acid rinsed in distilled water. Amounts greater than $0.05 \% \mathrm{Si}$ are measured in $1-\mathrm{cm}$ cells.

To test both methods, stabilized zirconias, free from both elements, were taken. Known amounts of aluminium and silicon were added; the materials were analysed according to the Procedures. The results are shown in Table 2. It can be concluded that the methods described are reliable with an accuracy acceptable for the materials described. They may also be applicable to allied materials.

The author thanks Dr. K. J. de Vries and Professor A. J. Burggraaf for their stimulating interest.

\section{REFERENCES}

1 J. Fries, Spurenanalyse, E. Merck, Darmstadt, 1971, p. 6.

$2 \mathrm{~J}$. Marinsky and Y. Marcus, Ion Exchange and Solvent Extraction, M. Dekker, New York, Vol. 5, 1973 , p. 169.

3 T. R. Andrew and C. H. R. Gentry, Analyst, 81 (1956) 339. 